\title{
The Tourist Potential in the Northern Coastal Areas Management and Protection of Natural Resources of the Area
}

\author{
Mirela Tase \\ University "Aleksander Moisiu" of Durres, Albania \\ Email:mirelatase@hotmail.com; \\ Manjola Xhaferri \\ University "Aleksander Moisiu" of Durres, Albania \\ Email:mxhaferri@yahoo.com
}

\section{Doi:10.5901/ajis.2015.v4n2s1p147}

\begin{abstract}
In the study of the coast in today's conditions for the development of our country it has become necessary for tourism and in particular the medical development to be seen as one of the main priorities for our economy. Knowing the characteristics of the coastal area, the natural values and its potential economic exploitation right of rational investment serves sustainable energy industrial parks which are being built in this part of the coast. In order to achieve sustainable development in the study area through environmental protection and tourism development has to assign. a. natural potentials offered by this coastal zone; $b$. management measures for their protection. The aim of this paper includes appreciating natural potentials that are owned by the coastal area to enable their use in a more rational way. The naturally dynamic and rapid socio-economic reflections on the coastal landscape of the area should be recorded and provided by geographic studies to serve society in the future and to minimize the negative phenomena.
\end{abstract}

Keywords: management, measures, environmental

\section{Introduction}

The natural environment is revealed as one of the major opportunities of the country, especially for attracting tourism. In this context, rich habitats and the spread of wetlands of North Coastal Region rank as a primary tool for such a strategy.The advantages of the region to study is the size of the area of these natural environments. In particular, is the terrestrial coastal belt with concentrations of the coastal lagoons and wet lands, Drini-Mati-Ishëm rivers. These natural areas can be attract for visitors who are interested in combining their holiday with studying and gaining an experience of nature, but also of importance that a greater number of tourists must be connected and interested in the environment.

These tourists are seeking the diversification of environmental characteristics and a high environmental quality. Natural routes and areas with high biodiversity can be separated and managed with care for such purposes. The coastal belt is also a available for the development opportunities related to tourism and leisure. Having and giving the status of natural diversity of lagoons and wetlands of the area-based tourism on the environment is not only sensitive for these habitats but also increases more compact development options for the area.

However, the sensitivity of the wetlands and associated coastal systems from people's input, tourism in this area should be allowed in specific areas with a low intensity scale, in groups rather than spread along the coast, and to be closely associated with the creation of a zone defense system for all North Coastal region. Protected areas such as should include a set of interventions from strict nature reserves to those inputs directed and administered in reserves with interpretive facilities

The Coastal corridor is narrow ecologically and can not afford "mass tourism" (beaches and ecological barriers) to a high degree. Promotion of this area as an example of the mixture of ecotourism environmental protection can be a model for other Mediterranean countries as well as an awakening like a sense of pride to the local community. But compared with the Southern Coastal region, beaches and sea water is less attractive, because they are not far from the local towns (Shkodra). In addition, in some areas as Velipoja, conditions are attractive to the local and regional perspective. 


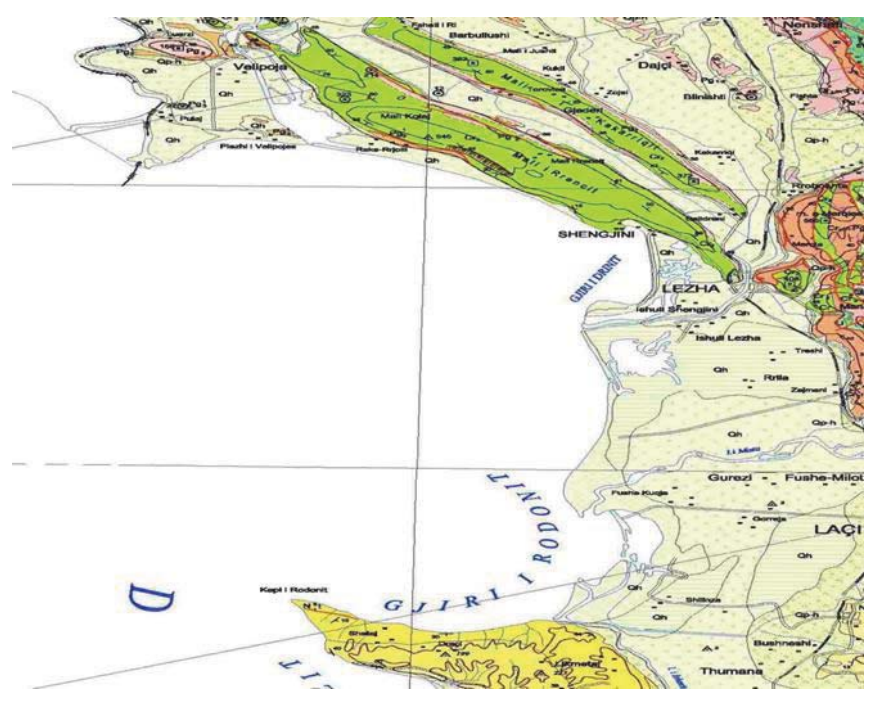

Map 1. Map of the coastal zone between the mouth of the river Buna and Cape of Rodon (northern coastal area) scale 1: 50,000 Its worked by Mirela Tase

\section{Features of the Area}

Other options may be also present in this area for the development of wet soils and lagoons that are associated with hunting and fishing. This can be accomplished in a limited scale and always within the context of ecologically sound administrative principle. The possibility of using these areas for hunting and fishing can be adjusted to the basic areas. The flow of water and the quality should be in the spotlight of regional efforts for coastal resource and management area.

One of the most serious shortcomings of the north coast area is environmental management or rather lack of it, which is in view of the prospects of these sectors or others associated with giving it encroachment towards a development perspective. That is exactly the basis of economic recovery and resources. The involved issues are complex because they affect the social, economic, physical / functional. Such as considerations, although in the past were seen as implications of economic developments in the $90 \mathrm{~s}$ and today are seen as prerequisites for growth. To maintain tools and natural of resources is essential. This at first glance gives the impression of a modern tendency to destroy the control of the state but from all final analysis it is clear that this region needs a better administration. Better management is essential for a sustainable growth. Rational management does not depend exclusively from financial resources. The main obstacle is usually used by institutional establishment, lack of direction, the control and effective propulsion mechanisms.

In relying on the coastline, two geographic areas, can be identified:

* The area that stretches from Buna -to Shengjin river (northern area)

* The area that stretches from Shëngjin- to Ishmi river (southern area)

* The northern zone is characterized by river gorges, agricultural fields and expansion Velipoje-Renc mountain. The southern area is characterized by sucking Shengjini and wet lands of the Rodon cape.

From analyzing the characteristics and dynamics of the coastal zone we have identified three areas coupling:

$>$ The strip of land near the sea, that is a $300-400 \mathrm{~m}$ wide area, on both sides of the coast including beaches, lagoons and coastal wetlands.

$>$ The intermediate zone of several kilometers, which includes farmland, hills, plains and transport axes setting.

$>$ The deep area which includes parts of mountainous areas around various mountain ranges.

The important role of coastal habitats in the narrow northern shore gives considerations to biodiversity and ecology and should be the first. We should determine the level of development that the area has to face. It is essential that the effects of activities in the region it is an opposite direction and close to be considered. Establishing criteria and the creation of "sensitive areas ecological" (Z) should be done first, and from this point of view there should be a 
determination of their various fields and protected areas. This should be done in the form of a general strategy for all coastal biodiversity, taking into account various sources of the pollution. Therefore a parallel strategy on pollution parameters based on known European criteria and Mediterranean necessary.

\section{Touristic Developments}

The tourism is already being increasingly recognized as an important source of exchange with the outside. However the construction of other facilities may have direct consequences on the environment where you can not set properly.There may be significant loss of natural capital as a result of inadequate planning along, with the destruction of the coastline and an esthetic image decrease towards tourists.

The touristic activity can have a negative impact on ecosystems for instance, that can cause pollution boats and anchors that can destroy sensitive habitats under water, such as sea barore mattresses. Degraded tourist areas can be given a negative image of an area which could finalize current investments and future. Therefore it is important to link tourism with natural conservation through the establishment of standards not only environmental but also ensuring that large areas are stored.

The protected areas (which means natural reserves, national parks and scenic landscapes) are important points that can be attract by people and they are a source of income for local communities and for the national one. In this way the creation of tourism is focused on protected areas can be help to diversify the economic underpinnings of the agricultural economy. Protected areas are an indication that the aesthetic and ecological criteria for sustainable tourism should be taken into account. This helps to promote scientific exchanges between different cultures and between people.

Since the tourist area have potential tourists should consider the following criteria:

- The acceptance naturally from the environment (s) and market (found)

- The circumstances satisfactory

- The interesting species

- The variety of activities

- The different standard accommodation and convenien

The attention must be paid to the potentially negative to impact parks and protected areas which are caused when not adjusted properly and become more populated. This may include invasions, pollution, recreation-based habitat, and destruction.

It is important to consider the carrying capacity. It is commonly used given the level of tourists. The criterion weight carrying the capacity also puts ecological capacity, fragility, lifestyle of wild animals of different species behavior, perception of visitors etc.

In the general, a country needs to have "opportunities" and "growth" to make an area more manageable, easier to travel through these areas (sidewalks and roads for cars) suitable places for visitors and educational facilities. The other possibilities includes the controlled activities during specific seasons or periods which must be environmentally and with a common interest.

The "increase" of countries leads directly to specific infrastructure developments for use on trucks, small roads, and other infrastructure services. To protected areas and parks, which attention should be higher in interaction with nature and infrastructure should include such criteria as

\section{To Be Non-intrusive}

$\$$ Using the local style

* To be a presentation and demonstration of renewable and non-polluted energy.

Sometimes in tourism development the time frame is very short and at the same time local communities should coexist with positives and negatives for the future generations. In this regard should be pressured both nationally as well as locally to encourage developers to contribute in the field of environment which is an area that has to do with their investments. Examples related to this case are the construction of sewer systems and waste water purification.

Another example of the appropriate infrastructure is using of existing ports and harbors than the construction of youth which will affect more shoreline processes. This is an ideally that would help to expand an existing area,like Shëngjini port where is very worn and poor. In this way the development, is contributing to the local economy of the area. To continuine principles under local contributiors, developers should try to train and employ local people, to use the resources of the country and try to distribute the funds throughout the region and country. It is also development requires 
of national legislation and a strong commitment to local scale. In this context, the funds of generated abroad is smaller when the infrastructure is based on local resources and environmentally is completed.

\section{Measures to be Taken for the Management of Tourist Potential Areas}

The Velipoje tourist center in tourism development plan should ensure the presence of roads and buildings for the accommodation of tourists in groups rather large and not focused in order to avoid distribution all along the coast. The beach areas should be create toilets, showers and other facilities for special tourist. The zone must organized the games and entertainment should be placed away from the coast and nearby wooded area. The structure as small mole of the boards for a limited access of the sea can be created to support water sports activities.

In the Viluni lagoon area eco-tourism area is needed Renc mounting to provide running water and high quality. In this area can be practiced fishing and some recreational activities. Having limited entrance on the eastern and southern part of the canal, the separated areas for the cultivation of fish eggs and ecological studies including their continuous monitoring. The area should be protected as a managed resource area (in agreement with IUCN).

The Renc mountain is an area with a great potential meaning in this case study to establish the natural camping for limited and controlled to enjoy peaceful holiday in nature. We should to create a small service center.The Viluni lagoon where you can go from the tourist center of Velipoje needs to used the walking. We can create the riding dirty foot of the hills away from the coast of the sea, underwater sports, placing small camps in specific areas and vazhdueshëm. The zone should be included in the defense as a protected landscape (IUCN category V).

The Shengjin- Lezha area needs an integrated management plan. The Shengjini area should be treated as a holiday center with an average intensity for vacationers and daily visitors. This plan should be aimed at developing for recreation area along the coast, including the port which is being transformed into a fishing center by limiting the entry of vehicles for commercial and preferably to be connected of the southern ports. Along the coastal villages can be built several commercial facilities (such as taverns, small shops) with small intense entertainment center. The hotels can create a small size and mediocre coastal areas can be equipped with small passages various entertainment centers at sea.

The back belt land can be established area with the sports fields. The limited number of service centers can be created in two or three groups which can be accessed by road. The small number of roads can be created which can be used for hiking, climbing, horse riding. The beaches can be used for swimming or any other water sport, that can be supported by the fixture not heavy at the visitor center.

The reserves coastal lagoons to Drini-Mati-Ishmi should be developed according to a plan of protection (IUCN) is considering the quality and quantity of natural water flow in the area. In this sense planned controls should be linked with the development plan based to agriculture in rural areas, opportunities for the agricultural / livestock for a limited culture and monitoring system is needed. This area serves to protect biodiversity allowing limited access to educational purposes, trails, deep zone of intermediate to visitor centers, ecotourism centers and roads that serves for the observation of nature. The limited-access areas should be identified for seasonal hunting.

The measures are aimed at:

$\checkmark$ To prepare the strategy for coastal biodiversity. This should be part of a major effort to be made in the study area that have potential significant biodiversity by a reflecting the general policy directions.

$\checkmark$ To develop a scheme for coastal protected area that have to study. This should include a number of options for protected areas are based on different environmental requirements.

$\checkmark$ To suggested actions are based on observations that can be recommended are as follows:

$\checkmark$ The natural reserves should have only a limited access to educational and scientific purposes as the of Franz Joseph Island is hunting reserve of the complex of wetlands / barrier island on the northern side of the Drin river and barriers complexes Patoku island in the lagoon.

$\checkmark$ The restoration and protection of the wetlands. These areas should be supported to maintain appropriate levels of fishing, hunting and good limited other wetlands, egz filtering, productivity etc. They need to have buffer zones which allow only non-polluting activities, especially should be not obstacles to agricultural and industrial inputs. This includes Viluni lagoon between Shëngjini and Lezha, south of the Drin river and Patok lagoon. There should be undertaken any activity of the filling from these areas. Instead of investment in the technology of cleaning sewage and solid waste the management of following should be considered to nearby Velipoje Shëngjini, Lezha cities. 


\section{Conclusions}

1. The coastal zone is between the mouth of the Buna river and cape of Rodon (North Coastal region), which occupies an important area of the Adriatic and owns $25 \%$ of the coastline of the Adriatic in our country.

2. The distinguished great value of natural coastal landscape (lagoon, delta, beaches, dunes, faleza, arrows) and great natural value as a fertile lands, dense vegetation varied, appropriate climatic conditions, a dense network of river, large quantities of groundwater.

\section{Recommendations}

1. The first character must take measures to protect the beaches engineering using French and Italian experience through barriers cemented located to opposite currents that transport alluvium preventing them and creating recreational areas.

2. The second creation is legislation for the protection of beaches, dunes, across the coast as a whole.

3. To the preserve ecological conditions, especially in lagoons and delta is order to preserve biodiversity of flora and fauna which is necessary for the ecological tourism.

4. We should not develop mass tourism areas and Shëngjini,Velipoje cities which are for elite tourism but that which enables the preservation of the environment protected areas that exist in them.

5. We should develop the medical tourism in isolated areas such as Rana beach. There shoud existed a project for Shengjini beach and using of Rana beach.

\section{References}

Axhemi.S,Hoti.M,"Velipoje coast, today's problems and prospects",National Symposium III of Geography,1998

Axhemi.S, Hoti.M, "The main directions of Velipoja administration beach resort" National Symposium III of Geography,1998

Council of Lezha, "Lezha region Reality Perspective", 2001

K. A.M King, "Beaches and Coast,"1963

Trojani.V, "Evolution of the coastline in the delta sector Drin of Lezha - Paddle tail and catastrophic occurrences that appear in the" National Symposium on Applied geomorphology, Geographical Studies, No. 12, Publication, 1999

Environment Protection Committee (CEP) 